А. С. Попович,

кандидат філологічних наук, професор

(Кам’янець-Подільський національний університет імені Івана Огієнка)

likalika@409@gmail.com

ORCID: $0000-0002-3428-9717$

\title{
ОБГРУНТУВАННЯ ДОЦІЛЬНОСТІ ПРОВЕДЕННЯ ЛАБОРАТОРНИХ ЗАНЯТЬ ІЗ СТИЛІСТИКИ УКРАЇНСЬКОЇ МОВИ В ЗАКЛАДАХ ВИЩОЇ ОСВІТИ
}

У статті з'ясовано питання доцільності виокремлення лабораторних занять із дисципліни

"Стилістика украӥнської мови". Подано визначення лабораторних занять зі стилістики й

охарактеризовано їх види за дидактичним спрямуванням, метою, змістовим наповненням,

організачійними особливостями та способами використання технологій навчання. Визначено продуктивні різновиди роботи на заняттях такого типу й запропоновано тематику лабораторних занять зі стилістики украӥнської мови.

Ключові слова: лабораторне заняття, стилістика украӥнськоїмови, стилістичне редагування, стилістичне трансформування, стилістичний аналіз, текстотворення, творча робота.

Постановка проблеми в загальному вигляді та їі зв'язок із важливими науковими і практичними завданнями. Освітянські реалії сьогодення свідчать про завершення "ери" транслювання й відтворення знань і перехід до самостійної пошуково-дослідницької діяльності студентів, а також уміння творчого розв'язання різноманітних питань і проблем.

Навчальні плани підготовки бакалаврів галузі знань 01 Освіта / Педагогіка спеціальності 014 Середня освіта (Українська мова і література) із курсу "Стилістика української мови" визначають такі форми проведення занять, як лекції й практичні заняття. Лекції передбачають засвоєння студентами теоретичного матеріалу, завдання практичних занять - поглибити та закріпити теоретичні положення навчальної дисципліни й звернути увагу на їх практичне застосування. Водночас сьогодні самостійна пізнавальна діяльність майбутніх учителів має спрямовуватися на вміння думати, самостійно віднаходити інформацію й критично іiі оцінювати. Актуалізуються такі загальні компетентності, як здатність до навчання, креативність, володіння технологіями пошуку інформації, гнучкість мислення тощо. Нагальним стає вміння викладача організовувати самостійну й індивідуальну роботу студентів, відтак постає потреба пошуку належних форм опанування дисципліною "Стилістика української мови", що підвищить ефективність підготовки вчителів-словесників.

Аналіз основних досліджень і публікацій із зазначеної проблеми. Лабораторні роботи є важливою формою організації освітнього процесу на філологічних факультетах вищих навчальних закладів педагогічного спрямування. Загальні аспекти проведення лабораторних занять у вищій школі досліджували С. Вітвицька, 3. Курлянд, В. Ортинський, 3. Слєпкань, Т. Туркот, М. Фіцула та інші. На особливості лабораторних занять у формуванні професійної компетентності майбутніх учителівсловесників побіжно звертали увагу О. Горошкіна, Н. Дейниченко, Т. Донченко, В. Дороз, О. Караман, С. Караман, К. Климова, В. Коваль, А. Нікітіна, О. Копусь, І. Олійник, М. Пентилюк, О. Семеног та інші.

Окреслення невирішених питань, порушених у статті. Водночас багато питань, пов'язаних із організацією й проведенням лабораторних занять, дотепер потребують обговорення й перевірки в практичній діяльності викладачів закладів вищої освіти.

Мета статті - визначити доцільність лабораторних занять із стилістики української мови як форми організації освітнього процесу у вищій школі й аспектно охарактеризувати їх теоретично-методичні засади.

Виклад основного матеріалу 3 обгрунтуванням отриманих наукових результатів. Лабораторні заняття за своїми сутнісними ознаками (мета й завдання проведення, зміст, види робіт, технологія проведення, ступінь індивідуальності тощо) достеменно відрізняються від практичних [1]. Означеним аспектам присвячені окремі студії К. Климової [2: 223; 3], актуалітетом яких є дослідницькі лабораторні роботи 3 курсу практичної стилістики сучасної української мови на соціально-психологічному факультеті. Ми погоджуємося, що "На лабораторних заняттях обдаровані студенти розвивають свої творчі здібності, відчувають емоційну насолоду від досягнутих успіхів, що надзвичайно оптимізує процес вивчення практичної стилістики сучасної української мови" [3]. Лабораторні заняття зі стилістики також виокремлюють І. Коломієць [4] і Р. Саакьян [5]. Лабораторні заняття із зазначеного курсу передусім спрямовуються на вироблення практичних умінь і навичок студентів, зокрема визначати стильові й жанрові мовні ознаки текстів, естетичну вартість мовних засобів, здійснювати редагування текстів, навчитися добирати мовні засоби відповідно до призначення, мети, завдань й ситуації спілкування, оволодіти вмінням текстотворення, раціонально використовувати час на аудиторному занятті. До того ж, на цих заняттях надається перевага самостійній роботі студентів і виконанню творчих 
завдань. Для майбутніх учителів української мови і літератури вартісним є не стільки виконання окремих (розрізнених) стилістичних вправ і завдань, скільки спеціальне систематичне стилістичне вправляння відповідно до обраної особистісно-індивідуальної стратегії навчання.

Під лабораторним заняттям зі стилістики української мови розуміємо форму навчального заняття у закладах вищої освіти, на якій у студентів у процесі індивідуальної самостійної роботи під керівництвом викладача формуються стилістичні компетентності майбутнього вчителя-словесника, розвиваються вміння здійснювати стилістичний аналіз текстів різних стилів і жанрів, розширюються й поглиблюються практичні аспекти стилістики тощо.

Аналіз наукової літератури (Б. Мокін, Т. Туркот, М. Фіцула та інші) дозволив виокремити такі види лабораторних занять зі стилістики:

1) за дидактичним спрямуванням: підтверджувальні, відтворювальні (або репродуктивні), частковопошукові, науково-дослідницькі (або пошукові);

2) за метою й змістовим наповненням: часткові й узагальнювальні;

3) за організаційними особливостями: фронтальні (або колективні), групові (або бригадні), індивідуальні;

4) за способами використання технологій навчання: традиційні й заняття із залученням інноваційних технологій.

Основне завдання підтверджувальних лабораторних робіт - засвідчення правильності отриманих теоретичних знань зі стилістики. Для відтворювальних робіт добираються стилістичні завдання, що виконуються за детальними інструкціями. Частково-пошуковий різновид робіт стимулює самостійність $\mathrm{i}$ творче мислення студентів, доцільний вибір шляхів розв'язання проблем і способів їх виконання. Розв'язання нових стилістичних проблем із високим ступенем самостійності передбачають науководослідницькі лабораторні роботи.

Лабораторні заняття часткового типу $є$ підготовчими, адже передбачають вироблення вмінь застосовувати теоретичний матеріал зі стилістики, орієнтуватися в ньому, добирати ті або ті мовні засоби, розвивають навички трансформування й редагування текстів, написання творчих робіт (текстотворення) тощо. На узагальнювальних лабораторних заняттях студенти виконують частковий (фонетично-стилістичний, лексико-стилістичний, словотвірно-стилістичний, морфолого-стилістичний, синтаксично-стилістичний) і повний (комплексний) стилістичний аналіз текстів і застосовують системні стилістичні знання. Такі лабораторні заняття завершують вивчення того чи того розділу курсу із засвоєння стилістичних ресурсів української мови й стилістики загалом.

Формами проведення лабораторних робіт є:

1. Фронтальні, або колективні, лабораторні роботи - це виконання студентами академічної групи тотожного завдання на матеріалі однакового дидактичного матеріалу, перевірка якого на підсумковому етапі заняття здійснюється через доповнення відповідей одногрупників. Тут добирається, наприклад, для здійснення стилістичного аналізу текст підвищеного рівня складності (наукового або публіцистичного стилю), що передбачатиме різні потлумачення, наявність неоднакових поглядів студентів тощо.

2. Групові, або бригадні, лабораторні роботи якнайбільше дозволяють здійснювати диференційований підхід, враховувати індивідуальні особливості студентів та їх інтереси. Члени певної групи (бригади) працюють над однаковим завданням, допомагають один одному, навчаються здійснювати контроль, самоконтроль і взаємоконтроль. Однак на наступному етапі заняття студенти академічної групи ознайомлюються 3 роботою один одного, що уможливлює одночасне сприйняття матеріалу різної складності й неоднакових практичних завдань.

3. Індивідуальні лабораторні роботи спрямовуються на виконання індивідуальних завдань і добір диференційованого дидактичного матеріалу (наприклад, текстів для аналізу або редагування). Студенти визначають індивідуальну траєкторію роботи, свій темп і ритм. За таких умов їх індивідуальність виявляється найвищою мірою.

Відповідно до способів використання технологій навчання виокремлюють традиційні й заняття із залученням інноваційних технологій. Наприклад, підсумкове лабораторне заняття, на якому здійснюється повний стилістичний аналіз тексту, можна провести у формі створення проектів (колективних та індивідуальних) і презентувати їх у форматі Power Point.

Продуктивними різновидами роботи на лабораторних заняттях зі стилістики української мови вважаємо стилістичне редагування, стилістичне трансформування, стилістичний аналіз, текстотворення, написання творчих робіт тощо. Віднаходити стилістичні огріхи й помилки і класифікувати їх студенти навчаються через стилістичне редагування текстів. Ця робота допомагає майбутнім філологам критично ставитися до власного мовлення, помічати й виправляти стилістичні недоліки в текстах, сприяє розвиткові й зміцненню стилістичних навичок, підвищенню стилістичної вправності. В. Мельничайко стверджує: "редагування може полягати в усуненні неточних, двозначних висловів, в урізноманітненні застосованих мовних засобів, в забезпеченні єдності стилю, у зміні стилістичного забарвлення. Певних змін може вимагати композиція тексту, навіть його обсяг" [6: 155]. Стилістичне трансформування текстів 
виробляє в студентів свідоме ставлення до відбору мовних засобів, адже потрібно передати поданий зміст тексту за допомогою засобів, притаманних іншому стилю [7: 333]. Застосовуючи стилістичний аналіз тексту, студенти осмислюють, повторюють, поглиблюють й узагальнюють відомості зі стилістики. До того ж, у подальшому це створює підвалини для вмотивованого добору й використання мовних засобів у власних висловлюваннях. На думку Т. Симоненко, показником сформованої професійної мовнокомунікативної компетенції студентів філологічного факультету є вміння створювати навчальні тексти різних функціонально-змістових типів [8: 176]. На часі вивчення основних вимог до дистанційного спілкування (культура спілкування по телефону і в Інтернеті) й правил мовленнєвої поведінки в спілкуванні (етичні мовленнєві формули). Майбутні фахівці повинні вміти здійснювати телефонні розмови, писати листи електронною поштою і по мобільному телефону (sms). $\mathrm{C}$ потреба працювати над текстотворенням рекламних, політично-агітаційних, офіційно-ділових, наукових, медійних, PR-текстів.

Пропонуємо такі орієнтовні теми лабораторних робіт з дисципліни "Стилістика української мови", якот: "Поняття стилістичної та стильової норми. Стилістичні помилки. Стилістичне редагування текстів"; "Стилістичне трансформування текстів", "Фонетико-стилістичний аналіз художнього тексту", "Лексикостилістичний аналіз художнього тексту", "Аналіз морфемно-словотворчих засобів художнього стилю", "Морфолого-стилістичний аналіз художнього тексту", "Синтаксично-стилістичний аналіз художнього тексту", "Повний лінгвостилістичний аналіз художнього тексту" тощо.

Проведення лабораторних занять формує в студентів уміння розпізнавати стилістично марковані мовні одиниці й декодувати їх, визначати ознаки індивідуального стилю, аналізувати тропи й фігури, а також удосконалює вміння аналізувати мовні засоби з погляду їх виразовості й функцій у певному тексті. Важливим є грамотне послуговування лінгвістичною і стилістичною термінологією, володіння методикою й поняттєвим апаратом стилістичного аналізу, стилістично коректна побудова тексту аналізу, вміння логічно, точно й доказово репрезентувати аналіз тексту й відстоювати свої погляди й позиції та правильно оформлювати стилістичний аналіз тексту.

За твердженням 3. Слєпкань, "Лабораторні роботи не стільки закріплюють теоретичні знання, скільки дають можливість студентові глибоко і наочно вивчити механізм застосування теоретичного матеріалу, оволодіти надзвичайно важливим для фахівця вмінням інтелектуального проникнення у ті <..> процеси, які досліджуються в лабораторному практикумі" [9: 125]. Ця форма занять дозволяє об'єднати теоретикометодологічні знання й практичні навички щодо майбутньої науково-дослідницької діяльності.

Лабораторні заняття зі стилістики української мови вимагають активної пошуково-дослідницької діяльності студентів, вміння інтегрувати знання стилістики із багатьма мовознавчими дисциплінами, зокрема сучасними (психолінгвістикою, прагмалінгвістикою, когнітивною й комунікативною лінгвістикою тощо), літературознавством, філософією, логікою, психологією, естетикою і сприяють вироблення стилістичних умінь і навичок, мовного чуття, а також набуттю стилістичної компетентності тощо.

Насамкінець зауважимо, що впродовж лабораторних занять важливо підвищувати рівень самостійності студентів, модернізувати структуру проведення занять, впроваджувати інноваційні, інтерактивні й мультимедійні технології тощо. До переваг лабораторних занять зі стилістики української мови варто зарахувати пришвидшення процесу засвоєння студентами стилістичного матеріалу; змогу узагальнення, систематизації, закріплення й поглиблення знань зі стилістики; вироблення практичних умінь і навичок із стилістики української мови; використання їх як засобу контролю й самоконтролю отриманих знань; формування загальних і спеціальних стилістичних компетентностей та інше.

Висновки та перспективи подальшого дослідження проблеми. Виокремлення лабораторних робіт з курсу стилістики, їх чітке відмежування від практичних занять, допоможе досягти кращих результатів у засвоєнні стилістичної теорії, прищеплення стилістичних умінь i навичок, формуванні навичок дослідницької роботи, набутті стилістичної компетентності, формуванні професійних навичок і вмінь.

Лабораторні заняття - особлива форма аудиторної роботи, якій притаманні специфічні, методи й прийоми, спеціальну систему завдань. Вони підвищують рівень стилістичної компетентності випускника закладів вищої освіти педагогічного спрямування. Використання на лабораторних заняттях стилістичного аналізу тексту, редагування текстів, їх трансформування підвищує рівень знань студентів із стилістики, розвиває творчі й інтелектуальні здібності. Лабораторні заняття якнайкраще поєднують навчальну й дослідницьку діяльність студентів і допомагають застосовувати засвоєні студентами способи діяльності в новій ситуації.

Подальші дослідження вбачаємо в укладанні методичних рекомендацій до проведення лабораторних занять із стилістики української мови.

\section{СПИСОК ВИКОРИСТАНИХ ДЖЕРЕЛ ТА ЛІТЕРАТУРИ}

1. Попович А. С. Лабораторні заняття з методики навчання української мови, їх специфіка та особливості проведення / А. С. Попович // Педагогічна освіта : теорія і практика : збірник наукових праць. - Кам'янецьПодільський національний університет імені Івана Огієнка; Інститут педагогіки НАПН України [гол. ред. 
Лабунець В. М.]. - Кам’янець-Подільський : ПП Зволейко Д. Г., 2016. - Вип. 20 (1-2016). - Ч. 2. - С. 399 405.

2. Климова К. Я. Теорія і практика формування мовнокомунікативної професійної компетенції студентів нефілологічних спеціальностей педагогічних університетів : [монографія] / К. Я. Климова. - Житомир : РУТА, 2010. $-562 \mathrm{c}$.

3. Климова К. Я. Формування мовностилістичної вправності у контексті професійної підготовки практичних психологів і соціальних педагогів / К. Я. Климова // Вісник Житомирського педагогічного університету. Серія "Педагогічні науки". - Житомир, 2004. - № 14. - С. 7-10.

4. Стилістика української мови : [навчально-методичний посібник для студентів-філологів вищих навчальних закладів денної та заочної форм навчання] / укладач I. І. Коломієць. - Умань : ФОП Жовтий О. О., 2016. $160 \mathrm{c}$.

5. Саакьян Р. Я. Практическая стилистика русского язика : лабораторные работы / Р. Я. Саакьян. - Ростов : Изд-во Ростовского университета, 1992. - 62 с.

6. Мельничайко В. Я. Творчі роботи на уроках української мови : Конструювання. Редагування. Переклад / В. Я. Мельничайко. - К. : Рад. школа, 1984. - 223 с.

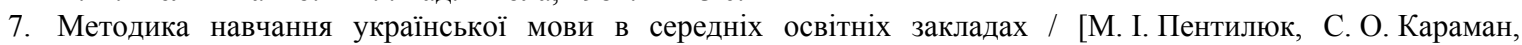
О. В. Караман, О. М. Горошкіна та ін.]; за ред. М. І. Пентилюк. - К. : Ленвіт, 2005. - 400 с.

8. Симоненко Т.В. Реалізація текстоцентричного підходу в процесі формування професійної мовнокомунікативної компетенції студентів-філологів / Т. В. Симоненко // Педагогічні науки : [збірник наукових праць]. - Херсон : Видавництво ХДУ, 2008. - Вип. 48. - С. 174-178.

9. Слєпкань 3. І. Наукові засади педагогічного процесу у вищій школі / 3. І. Слєпкань. - К. : Вища школа, 2005. -239 c.

\section{REFERENCES (TRANSLATED \& TRANSLITERATED)}

1. Popovych A. S. Laboratorni zaniattia z metodyky navchannia ukrains'koi movy, yikh spetsyfika ta osoblyvosti provedennia [Laboratory Classes in Methods of Teaching Ukrainian Language, Their Specificity and Conducting Peculiarities] / A. S. Popovych // Pedahohichna osvita : teoriia i praktyka [Pedagogical Education: Theory and Practice] : [zbirnyk naukovykh prats']. - Kamianets-Podilskyi natsionalnyi universytet imeni Ivana Ohiienka ; Instytut pedahohiky NAPN Ukrainy [hol. red. Labunets V. M.]. - Kamianets-Podils'kyi : PP Zvoleiko D. H., 2016. Vyp. 20 (1-2016). - Ch. 2. - S. 399-405.

2. Klymova K. Ya. Teoriia i praktyka formuvannia movnokomunikatyvnoi profesiinoi kompetentsii studentiv nefilolohichnykh spetsial'nostei pedahohichnykh universytetiv [Theory and Practice of Formation of Language Communicative Professional Competence of Students of Non-philological Specialties of Pedagogical Universities] : [monohrafiia] / K. Ya.Klymova. - Zhytomyr : RUTA, 2010. - $562 \mathrm{~s}$.

3. Klymova K. Ya. Formuvannia movnostylistychnoi vpravnosti u konteksti profesiinoi pidhotovky praktychnykh psykholohiv i sotsial'nykh pedahohiv [The Formation of Stylistic Competence on the Basis of the Professional Training of the Psychologists and Social Pedagogues] / K. Ya. Klymova // Visnyk Zhytomyrskoho pedahohichnoho universytetu. Seriia "Pedahohichni nauky" [Zhytomyr Pedagogical University Journal. Series "Pedagogical Sciences"]. - Zhytomyr, 2004. - № 14. - S. 7-10.

4. Stylistyka ukrains'koi movy [Stylistics of the Ukrainian Language] : [navchal'no-metodychnyi posibnyk dlia studentiv-filolohiv vyshchykh navchalnykh zakladiv dennoi ta zaochnoi form navchannia] / ukladach I. I. Kolomiiets. - Uman' : FOP Zhovtyi O. O., 2016. - 160 s.

5. Saakian R. Ja. Prakticheskaia stilistika russkogo yazyka : laboratornyie raboty [Practical Stylistics of the Russian Language: Laboratory Lessons] / R. Ja. Saakian. - Rostov : Izd-vo Rostovskogo universiteta, 1992. - 62 s.

6. Melnychaiko V. Ya. Tvorchi roboty na urokakh ukrains'koi movy : Konstruiuvannia. Redahuvannia. Pereklad [Creative Works in the Ukrainian Language Lessons : Design. Editing Translation] / V. Ya. Melnychaiko. - K. : Rad. shkola, 1984. - 223 s.

7. Metodyka navchannia ukrains'koi movy v serednikh osvitnikh zakladakh [Methodology of Teaching the Ukrainian Language in Secondary Education Establishments] / [M. I. Pentyliuk, S. O. Karaman, O. V. Karaman, O. M. Horoshkina ta in.] ; za red. M. I. Pentyliuk. - K. : Lenvit, 2005. - $400 \mathrm{~s}$.

8. Symonenko T. V. Realizatsiia tekstotsentrychnoho pidkhodu $\mathrm{v}$ protsesi formuvannia profesiinoi movnokomunikatyvnoi kompetentsii studentiv-filolohiv [Implementation of the Text-Centric Approach in the Process of Formation of Professional Linguistic Communicative Competence of Students-Philologists] / T. V. Symonenko // Pedahohichni nauky [Pedagogical Education] : [zbirnyk naukovykh prats'] - Kherson: Vydavnytstvo KhDU, 2008. - Vyp. 48. - S. 174-178.

9. Sliepkan Z. I. Naukovi zasady pedahohichnoho protsesu u vyshchii shkoli [Scientific Principles of Pedagogical Process in Higher School] / Z. I. Sliepkan. - K. : Vyshcha shkola, 2005. - 239 s.

\section{Попович А. С. Обоснование целесообразности проведения лабораторных занятий по стилистике украинского языка в учреждениях высшего образования.}

В статье выяснен вопрос иелесообразности выделения лабораторных занятий по дисииплине "Стилистика украинского языка". Даны определения лабораторных занятий по стилистике и охарактеризованы виды занятий по дидактическим направлениям, цели и смысловому наполнению, организационным особенностям и способам использования технологий обучения. Определень 
продуктивные виды работы на занятиях такого типа и предложено тематику лабораторных занятий по стилистике украинского языка.

Ключевые слова: лабораторное занятие, стилистика украинского языка, стилистическое редактирование, стилистическое трансформирование, стилистический анализ, текстообразование, творческая работа.

\section{Popovych A. S. Reasoning of Accessibility of Ukrainian Language Stylistics Laboratory Studies in Higher Education Establishments.}

Today's educational realities testify to the completion of the "era" knowledge's broadcasting and reproduction and the transition to independent research and student's research activities, the ability to creative solution of various issues and problems. The teacher's ability to organize student's independent and individual work becomes urgent, therefore, the need arises to find suitable forms of understanding the discipline "Stylistics of the Ukrainian language", which will increase the effectiveness teachers-philologists' preparation.

The article determines the expediency of laboratory lessons in the Stylistics of the Ukrainian language as a form of organization the educational process in higher education establishments and describes the methodical aspects of their realization.

The laboratory lessons in the Ukrainian language Stylistics is understood as the training session form in higher educational establishments, in which students develop the future teacher's Ukrainian languastylistic competences in the process of individual independent work under their teacher's direction, develop the ability to carry out stylistic text analysis of different styles and genres, expand and deepen practical aspects of stylistics, etc.

The types of laboratory lessons in Stylistics are characterized according didactic orientation (confirmatory, reproductive or reproductive, part-search, research or search), purpose and content (partial and generalized),

organizational features (front or collective, group or brigade, individual), learning technologies ways

(traditional and lessons with the use of innovative technologies). Productive work varieties on laboratory lessons in Stylistics of the Ukrainian language have been recognized as stylistic editing, stylistic transformation, stylistic analysis, text creation, creative writing, etc.

The advantages of laboratory lessons in Stylistics of the Ukrainian language include student's acceleration of the process assimilation of stylistic material; the possibility of generalization, systematization, consolidation and deepening knowledge in stylistics; development of practical skills in the Ukrainian language stylistics; use them as control means and knowledge's self-control; the formation of general and special stylistic competencies, and so on.

Key words: laboratory lesson, Stylistics of the Ukrainian language, stylistic editing, stylistic transformation, stylistic analysis, text creation, creative work. 